\title{
Performance of Released Hybrid Varieties of Pearl Millet (Pennisetum glaucum L.) under Rainfed Condition of Odisha
}

\author{
L. Nayak ${ }^{*}$, B. B. Dalei, S. K. Biswasi, K. Pradhan and P. Acharya \\ Regional Research and Technology Transfer Station (OUAT), Semiliguda, \\ Post Box No-10, Sunabeda, Dist-Koraput, Pin-763002 (Odisha), India \\ *Corresponding author
}

\begin{tabular}{|c|c|c|}
\hline & \multicolumn{2}{|l|}{ A B S T R A C T } \\
\hline $\begin{array}{l}\text { Hybrid varieties, } \\
\text { Productive tillers, } \\
\text { Panicle length, Test } \\
\text { weight, Yield }\end{array}$ & \multirow{3}{*}{\multicolumn{2}{|c|}{$\begin{array}{l}\text { The field experiment was carried out at Regional Research and Technology Transfer } \\
\text { Station (OUAT), Semiliguda of Koraput district in acidic sandy loam soils under Eastern } \\
\text { Ghat High Land zone of Odisha during kharif } 2019 \text { to evaluate the performance of } \\
\text { released hybrid varieties of pearl millet under rainfed condition. The experiment consisted } \\
\text { of sixteen released hybrid varieties of pearl millet viz. HHB 229, AHB 1200, 86 M 01, } \\
\text { NBH 5767, Pratap (MH 1662), NBH 4903, NBH 5061, } 86 \mathrm{M} \mathrm{86,} \mathrm{Kaveri} \mathrm{Super} \mathrm{Boss,} 86 \mathrm{M} \\
64 \text {, GHB 558, Dhanshakti, ICMV 221, Pusa Comp } 612 \text {, ABV } 04 \text { and ICMV } 155 \text {. It was } \\
\text { laid out in randomized block design with three replications. The results revealed that } \\
\text { Kaveri Super Boss recorded highest grain yield of } 4667 \mathrm{~kg} / \mathrm{ha} \text { among all the varieties/ } \\
\text { hybrids evaluated and it was statistically at par with the yield of NBH } 4903 \text { ( } 4536 \mathrm{~kg} / \mathrm{ha} \text { ) } \\
\text { and NBH } 5061 \text { ( } 4195 \mathrm{~kg} / \mathrm{ha} \text { ). The hybrid ICMV } 155 \text { recorded the lowest grain yield of } 567 \\
\mathrm{~kg} / \mathrm{ha} \text { under rainfed condition. }\end{array}$}} \\
\hline Article Info & & \\
\hline $\begin{array}{l}\text { Accepted: } \\
15 \text { August } 2020 \\
\text { Available Online: } \\
10 \text { September } 2020\end{array}$ & & \\
\hline \multicolumn{2}{|l|}{ Introduction } & $\begin{array}{l}\text { survive (Basavaraj et al., 2010). It is the rich } \\
\text { source of fibers and minerals especially iron, }\end{array}$ \\
\hline \multicolumn{2}{|c|}{$\begin{array}{l}\text { Pearl millet (Pennisetum glaucum L.) is a } \mathrm{C}_{4} \\
\text { plant with very high photosynthetic efficiency }\end{array}$} & \\
\hline \multirow{2}{*}{\multicolumn{2}{|c|}{$\begin{array}{l}\text { and dry matter production capacity. Its } \\
\text { growing areas are Africa and Indian }\end{array}$}} & least cost compared to wheat and rice. It is \\
\hline & & oted that demand for pearl millet from \\
\hline \multicolumn{2}{|c|}{$\begin{array}{l}\text { subcontinent where it is the only suitable and } \\
\text { efficient crop for arid and semi-arid regions }\end{array}$} & \\
\hline \multicolumn{2}{|c|}{$\begin{array}{l}\text { efficient crop for arid and semi-arid regions } \\
\text { because of its efficient utilization of soil }\end{array}$} & \\
\hline \multicolumn{2}{|c|}{$\begin{array}{l}\text { moisture, high level of heat tolerance and low } \\
\text { fertility than other typical dry land crops like }\end{array}$} & \\
\hline \multicolumn{2}{|c|}{$\begin{array}{l}\text { fertility than other typical dry land crops like } \\
\text { sorghum and maize (Shah et al., 2012). Due }\end{array}$} & $\begin{array}{l}\text { livestock as well as in house building fencing } \\
\text { and for fuel (Saba et al., 2015). However due }\end{array}$ \\
\hline \multicolumn{2}{|c|}{$\begin{array}{l}\text { to its tolerance to abiotic stress, pearl millet } \\
\text { can be grown in areas where other cereal }\end{array}$} & $\begin{array}{l}\text { to the high instability in grain yield and } \\
\text { decline in prices of pearl millet, farmers } \\
\text { might shift to other competing crops. }\end{array}$ \\
\hline
\end{tabular}


Improving crop yield under rainfed condition is important to maintain food security and improve livelihoods of the poor. Economical grain yield of $600-700 \mathrm{~kg} / \mathrm{ha}$ can easily be produced from pearl millet under marginal and low management conditions, with an additional ability to produce a grain yield of 4000-5000 kg/ha when hybrids (80-85 days maturity) are grown as summer crop under irrigated and high fertility conditions (Chaudhari et al., 2018). Hence production of pearl millet can be improved through growing high yielding varieties/hybrids with tolerance to drought, resistance to diseases and responding to higher rates of fertilizer applications. Sharma (2014) reported that hybrid cultivation is more profitable than indigenous OPVs of pearl millet in arid Rajasthan. Screening of hybrid varieties suitable for a particular region and climatic condition can help in boosting the production of pearl millet. Therefore the present experiment was conducted to evaluate the performance of released hybrid varieties of pearl millet under rain fed conditions of Odisha.

\section{Materials and Methods}

The field experiment was conducted at Regional Research and Technology Transfer Station (OUAT), Semiliguda, Koraput under Eastern Ghat High Land zone of Odisha, India during kharif 2019. The farm is located in the geographical parallels of $18^{\circ} 42^{\prime} \mathrm{N}$ latitude, $82^{\circ} 30^{\prime} \mathrm{E}$ longitude and an altitude of 884 meter above mean sea level. The region is marked by its wet and humid climate with an average annual rainfall of $1521 \mathrm{~mm}$ most of which is received from mid-June to midOctober. The soil of experimental site was characterized as sandy loam in texture with pH 3.9 (acidic), low in both organic carbon $(0.11 \%) \& N(248 \mathrm{~kg} / \mathrm{ha})$ and high in both $\mathrm{P}$ (48 kg/ha) \& K (519 kg/ha). The experiment was laid out in randomized block design with three replications consisting of sixteen released hybrid varieties as treatments viz. T1HHB 229, T2- AHB 1200, T3- 86 M 01, T4NBH 5767, T5- Pratap (MH 1662), T6- NBH 4903, T7- NBH 5061, T8- 86 M 86, T9Kaveri Super Boss, T10- 86 M 64, T11- GHB 558, T12- Dhanshakti, T13- ICMV 221, T14Pusa Comp 612, T15- ABV 04 and T16ICMV 155. Seeds were sown with seed rate of $5 \mathrm{~kg} / \mathrm{ha}$, spacing $50 \mathrm{~cm} \times 15 \mathrm{~cm}$ and fertilizer dose of 60:30:00 NPK kg/ha on $20^{\text {th }}$ July 2019. The data collected were subjected to statistical analysis in the randomized complete block design following the method of Gomez and Gomez (1984).

\section{Results and Discussion}

\section{Effect on growth parameters of pearl millet hybrids}

\section{Plant population}

The number of plants/ha at the time of harvest is one of the most contributing factor for grain yield. Statistical analysis revealed that final plant population at harvest differed significantly among the hybrids. Plant population was recorded maximum in $\mathrm{NBH}$ 5061 [87.3 ('000/ha)] and minimum in $86 \mathrm{M}$ 86 [25.3('000/ha] (Table 1). The marked variation in plant population might be due to variation in seed viability and/or1000 seed weight. The result confirmed the findings of Dhedhi et al., (2016) and Gupta et al., (2017).

\section{Plant height at harvest}

The plant height is a significant growth parameter directly involve with inter nodal distance and number of leaves which ultimately influence yield of grain and forage. Highest plant height was recorded in $\mathrm{NBH}$ $4903(182 \mathrm{~cm})$ followed by Kaveri Super Boss $(179 \mathrm{~cm})$ and NBH $5061(178 \mathrm{~cm})$ while lowest plant height was observed in GHB 558 
$(129 \mathrm{~cm})$ (Table 1). The variation in plant height in different hybrid varieties of pearl millet might be due to genetic makeup and environmental factor. Taller plants intercepted more solar radiation than shorter plants. Similar finding was reported by Yadav et al., (2014) and Sharma et al., (2019).

\section{No. of tiller/plant}

Hybrids showed a significant effect on no. of tillers/plant under favorable environment and soil conditions. Number of tiller per plant was found maximum in Kaveri Super Boss (3.7) followed by GHB 558 (3.3) and minimum in $86 \mathrm{M}$ 01(1.6) (Table 1). These results are in conformity with the findings of Detroja et al., (2018).

\section{Effect on yield attributing parameter of pearl millet hybrids}

\section{Panicle length and panicle diameter}

Panicle length and structure is an important agronomic trait in acceptance of variety by the farmers. Most pearl millet cultivars are characterized by long and compact panicles. Panicle length in most of the hybrids was significant $(\mathrm{P}<0.05)$. Data in Table 1 showed that longest panicle was found in NBH 4903 $(24.5 \mathrm{~cm})$ which was at par with NBH 5061 $(23.3 \mathrm{~cm})$ and Pusa comp $612(22.8 \mathrm{~cm})$ and shortest panicle in ICMV $221(14.8 \mathrm{~cm})$. Higher potentials were also exhibited by $86 \mathrm{M}$ 64, Kaveri Super Boss and NBH 5767 for production of longer panicles (Table 1). Pearl millet varies in panicle length, seed size, colour and plant height depending upon cultivars and environment. Significantly higher panicle diameter was recorded in NBH $5061(11.2 \mathrm{~cm})$ statistically higher than $\mathrm{NBH}$ $4903(11.0 \mathrm{~cm})$, ABV $04(10.2 \mathrm{~cm})$ and Kaveri Super Boss $(10.1 \mathrm{~cm})$. Lowest panicle diameter was observed in ICMV 155 (7.0 $\mathrm{cm})$. The results are in agreement with the findings of Choudhari et al., (2018) and Detroja et al., (2018).

\section{Days to $50 \%$ flowering}

Days to $50 \%$ flowering among all the sixteen pearl millet hybrid varieties was significantly different $(p<0.05)$ as shown in (Table 1$)$. Number of days to $50 \%$ flowering ranged between 63 and 71 (Table 1). The average day to $50 \%$ flowering was 67.1 days. This was an indication that the seasonal rainfall distribution affected days to $50 \%$ flowering among millet varieties. Similar results have been reported by Sharma (2014).

\section{0 seed weight}

Data showed in Table 1 indicated that there was significant effect of varieties on 1000 seed weight. Dhanshakti recorded the maximum seed weight of $15.2 \mathrm{~g}$ followed by NBH 4903 (11.0 g), Kaveri Super Boss (13.7 g) and NBH 4903 (13.4g) and minimum in ICMV 155 with seed weight $7.0 \mathrm{~g}$. The results are in agreement with the findings of Yadav et al., (2014) and Detroja et al., (2018).

\section{Yield}

Among the 16 hybrid varieties tested Kaveri Super Boss recorded the highest grain yield of $4667 \mathrm{~kg} /$ ha statistically at par with NBH 4903 (4536 kg/ha) and NBH 5061 (4195 kg/ha). The hybrid ICMV 155 recorded lowest grain yield (567 kg/ha) under rain fed condition. An increased in grain yield to a tune of $87.9 \%, 87.5$ $\%, 86.5 \%$ were recorded with the hybrid varieties Kaveri Super Boss, NBH 4903 and NBH 5061 respectively over the lowest yielding hybrid ICMV 155. It might be due to potential difference of varieties, plant population, panicle diameter, panicle length and 1000 grain weight. These findings were in concurrence with the results of Yadav et al., (2014), Detroja et al., (2018) and Choudhuri et al., (2018). 
Table.1 Growth parameters and yield attributes of released hybrid varieties of pearl millet

\begin{tabular}{|c|c|c|c|c|c|c|c|c|c|c|}
\hline Varieties & $\begin{array}{c}\text { Days to } \\
50 \% \\
\text { flowering }\end{array}$ & $\begin{array}{l}\text { Days to } \\
\text { maturity }\end{array}$ & $\begin{array}{c}\text { Plant } \\
\text { population } \\
\text { ('000/ha) }\end{array}$ & $\begin{array}{l}\text { Plant } \\
\text { height } \\
\text { (cm) }\end{array}$ & $\begin{array}{l}\text { Productiv } \\
\text { e tillers/ } \\
\text { plant }\end{array}$ & $\begin{array}{l}\text { Panicle } \\
\text { length } \\
\text { (cm) }\end{array}$ & $\begin{array}{c}\text { Panicle } \\
\text { diameter } \\
(\mathrm{cm})\end{array}$ & $\begin{array}{c}1000 \\
\text { seed } \\
\text { wt. }(g)\end{array}$ & $\begin{array}{c}\text { Grain } \\
\text { yield } \\
\text { (kg/ha) }\end{array}$ & $\begin{array}{c}\text { Harves } \\
\text { t index } \\
(\%)\end{array}$ \\
\hline T1: HHB 229 & 70 & 113 & 32.0 & 147 & 2.6 & 18.0 & 9.4 & 9.9 & 1237 & 44.33 \\
\hline T2: AHB 1200 & 64 & 105 & 58.6 & 146 & 2.2 & 19.5 & 9.3 & 11.9 & 1407 & 59.35 \\
\hline T3: 86 M 01 & 71 & 110 & 62.0 & 151 & 1.6 & 19.9 & 9.4 & 12.5 & 2493 & 53.81 \\
\hline T4: NBH 5767 & 69 & 110 & 68.0 & 166 & 2.4 & 20.6 & 10.0 & 11.2 & 2100 & 50.68 \\
\hline T5: Pratap (MH1662) & 70 & 108 & 62.7 & 141 & 2.4 & 17.9 & 9.4 & 11.5 & 1604 & 50.26 \\
\hline T6: NBH 4903 & 69 & 106 & 83.3 & 182 & 2.6 & 24.5 & 11.0 & 13.4 & 4536 & 52.81 \\
\hline T7: NBH 5061 & 69 & 106 & 87.3 & 178 & 2.3 & 23.3 & 11.2 & 12.9 & 4195 & 58.66 \\
\hline T8: 86 M 86 & 68 & 107 & 25.3 & 159 & 1.5 & 19.2 & 9.6 & 12.1 & 1124 & 55.34 \\
\hline T9: Kaveri Super Boss & 70 & 106 & 85.3 & 179 & 3.7 & 21.2 & 10.1 & 13.7 & 4667 & 52.73 \\
\hline T10: 86 M 64 & 69 & 106 & 48.0 & 166 & 3.2 & 21.6 & 9.8 & 13.6 & 1666 & 57.52 \\
\hline T11: GHB 558 & 65 & 112 & 13.3 & 129 & 3.3 & 18.0 & 9.2 & 10.4 & 630 & 69.24 \\
\hline T12: Dhanshakti & 63 & 105 & 52.0 & 144 & 2.2 & 17.9 & 8.5 & 15.2 & 1137 & 58.40 \\
\hline T13: ICMV 221 & 63 & 104 & 38.0 & 134 & 2.0 & 14.8 & 8.6 & 10.8 & 910 & 55.38 \\
\hline T14: Pusa Comp 612 & 65 & 106 & 32.0 & 171 & 2.8 & 22.8 & 8.1 & 9.0 & 1089 & 46.63 \\
\hline T15: ABV 04 & 66 & 107 & 42.0 & 166 & 3.1 & 18.1 & 10.2 & 11.4 & 1850 & 44.83 \\
\hline T16: ICMV 155 & 63 & 105 & 26.7 & 161 & 2.3 & 18.5 & 7.0 & 9.7 & 567 & 34.21 \\
\hline Grand Mean & 67.1 & 107.3 & 38.3 & 157.3 & 2.5 & 19.7 & 9.4 & 11.8 & 1950.6 & - \\
\hline $\operatorname{SEm}( \pm)$ & 1.2 & 0.8 & 5.5 & 5.7 & 0.2 & 0.8 & 0.3 & 1.1 & 247.5 & - \\
\hline $\mathrm{CD}(0.05)$ & 3.6 & 2.4 & 16.7 & 17.2 & 0.7 & 2.5 & 1.0 & 3.2 & 741.9 & - \\
\hline CV (\%) & 3.0 & 1.3 & 17.1 & 6.3 & 16.2 & 7.2 & 6.0 & 15.2 & 19.2 & - \\
\hline
\end{tabular}


Table.2 Estimates of correlation coefficients between yield and yield components of pearl millet

\begin{tabular}{|l|c|l|l|l|l|l|l|l|l|}
\hline Traits & $\mathbf{X 2}$ & \multicolumn{1}{|c|}{$\mathbf{X 3}$} & \multicolumn{1}{|c|}{$\mathbf{X 4}$} & $\mathbf{X 5}$ & \multicolumn{1}{|c|}{$\mathbf{X 6}$} & \multicolumn{1}{|c|}{$\mathbf{X 7}$} & \multicolumn{1}{|c|}{$\mathbf{X 8}$} & \multicolumn{1}{|c|}{$\mathbf{X 9}$} & \multicolumn{1}{|c|}{$\mathbf{X 1 0}$} \\
\hline $\mathbf{X 1}$ & 0.263 & $0.835^{* *}$ & $0.457^{*}$ & 0.240 & $0.563^{* *}$ & $0.364^{*}$ & -0.275 & -0.323 & $0.715^{* *}$ \\
\hline $\mathbf{X 2}$ & & 0.227 & 0.195 & 0.001 & 0.066 & 0.075 & 0.074 & 0.050 & 0.247 \\
\hline $\mathbf{X 3}$ & & & $0.511^{* *}$ & 0.267 & $0.569^{* *}$ & $0.433^{*}$ & -0.081 & 0.035 & $0.689^{* *}$ \\
\hline $\mathbf{X 4}$ & & & & $0.483^{* *}$ & $0.663^{* *}$ & $0.672^{* *}$ & 0.218 & $0.380^{*}$ & $0.762^{* *}$ \\
\hline $\mathbf{X 5}$ & & & & & $0.616^{* *}$ & 0.231 & -0.308 & $0.437^{*}$ & $0.535^{* *}$ \\
\hline $\mathbf{X 6}$ & & & & & & $0.516^{* *}$ & -0.181 & 0.104 & $0.884^{* *}$ \\
\hline $\mathbf{X 7}$ & & & & & & & $0.557^{* *}$ & 0.008 & $0.596^{* *}$ \\
\hline $\mathbf{X 8}$ & & & & & & & & 0.104 & -0.064 \\
\hline $\mathbf{X 9}$ & & & & & & & & & 0.099 \\
\hline
\end{tabular}

$(*, * *$ indicate significant at 0.05 and 0.01 probability levels respectively)

$\mathrm{X}_{1}$ : Plant height $\mathrm{X}_{2}$ : Tillers /plant $\mathrm{X}_{3}$ : Panicle length $\quad \mathrm{X}_{4}$ : Panicle diameter

$\mathrm{X}_{5}$ : Test weight $\mathrm{X}_{6}$ : Plant population $\quad \mathrm{X}_{7}$ : Days to $50 \%$ flowering $\mathrm{X}_{8}$ : Days to maturity $\mathrm{X}_{9}$ : Harvest index $\mathrm{X}_{10}$ : Yield

\section{Correlation studies}

\section{Association among growth parameters, yield attributes and yield}

The effect of growth parameters and yield attributes on grain yield in pearl millet was analysed through correlation studies (Table 2). On the basis of correlation coefficients it was observed that grain yield had highly positive and significant association with plant height, panicle length, panicle diameter, and test weight and plant population. Among the yield contributing characters plant height, panicle length and plant population had high positive correlation. Similar results were also reported by Sharma et al., (2014), Gupta et al., (2017) and Singh et al., (2018).

It is concluded that Kaveri Super Boss, NBH 4903 and NBH 5061 are the best suitable hybrid varieties of pearl millet for rainfed condition under Eastern Ghat high land zone of Odisha.

\section{Acknowledgement}

The authors would like to express their appreciation to Odisha University of
Agriculture and Technology, Bhubaneswar, Odisha, India for granting permission to use research facilities at RRTTS, Semiliguda, Koraput. Most sincere gratitude also goes to AICRP on Pearl millet, PC unit, ARS, Mandor, Jodhpur, Rajasthan for providing the Pearl millet accessions.

\section{References}

Basavaraj, G., Rao, P. P., Bhagavatula, S., and Ahmed, W. 2010. Availability and utilization of pearl millet in India. Journal of SAT Agricultural Research. 8.

Chaudhari,R. P., Patel, P. M., Patel, B. M., Upesh, K., Darji, S. S., and Patel, S. J.2018.Performance of summer pearl millet (Pennisetum glaucum L.) hybrids under North Gujarat conditions. International Journal of Current Microbiology and Applied Sciences. 7(1): 637-644.

Detroja, A. C., Bhuva, H. M., Chaudhari, N. N., Patel, P. R., and Kikani, V. L.2018. Production potential of improved pearl millet (Pennisetum glaucum L) cultivars under staggered sowing in raifed areas of western India. 
International Journal of Environmental Sciences \& Natural Resources. 12(4): 119-122.

Dhedhi, K. K., Ansodariya, V. V., Chaudhari, N. N., Sanghan, J. M., Mehta, A. C., and Sorathiya, J. S.2016.Fodder potential of pearl millet forage hybrids under rainfed conditions of Gujarat. International Journal of Bio-resource and Stress Management. 7(3):444-449.

Gomez, K. A., and Gomez, A. A.1984.Statistical procedures for agricultural research (2nd Ed.). John Wiley and Sons, New York, USA P: 680.

Gupta, A., Sharma, O. P., Yadav, S. S., and Solanki, R. B. 2017. Correlation studies in pearl millet as influenced by varieties and bio-regulators. The Pharma Innovation Journal. 6(2): 176-178.

Saba, I., Ahmed, H., and Liyu, U.2015. Growth and yield of pearl millet (Pennisetum galaucum L) as influenced by variety and intra- row spacing in Sokoto, North- Western Nigeria. Journal of Global Bioscience. 4: 26412648.

Shah, A. H., Rahman, H., Shah, S. M. A., Rahman, S., and Noor, M.2012.
Characterization of pearl millet germplasm for various morphological and fodder yield parameters. Pakistan Journal of Botany. 44: 273-279.

Sharma, N. K.2014. Evaluation of released varieties and hybrids of pearl millet for seed and stover yields in hot arid climate of Rajasthan. Indian J. Plant Genet. Resour. 27(1): 63-65.

Sharma, S., Kumar, A., Satyavan, A. K., Yadav, D. V., and Pathania, R.2019. Performance of pearl millet (L.) hybrids and their parents (B and $\mathrm{R}$ - lines) under rain fed \& irrigated situations. Journal of Agrometeorology. 21(1): 42-52.

Singh, M., Vijya Laxmi., Dabur, K. R., and Yadav, Y.2018. Performance of pearl millet (Pennisetum glaucum) cultivars under late sown condition in sandy loam soils. Research Journal of Chemical and Environmental Sciences. 6(2): 86-88.

Yadav, A. K., Kumar, A., Singh, J., Jat, R. D., Jat, H. S., Datta, A., Singh, K., and Chaudhary, R.2014. Performance of pearl millet genotypes under irrigated and rainfed conditions at Hisar, India. Journal of Applied and Natural Science. 6(2): 377-382.

\section{How to cite this article:}

Nayak, L., B. B. Dalei, S. K. Biswasi, K. Pradhan and Acharya, P. 2020. Performance of Released Hybrid Varieties of Pearl Millet (Pennisetum glaucum L.) under Rainfed Condition of Odisha. Int.J.Curr.Microbiol.App.Sci. 9(09): 1799-1804. doi: https://doi.org/10.20546/ijcmas.2020.909.225 